\title{
La vida por las ideas. \\ La retórica romántica del Kirchnerismo (Argentina, 2003-2015)
}

To die for your ideas.

The romantic rhetoric of Kirchnerism (Argentina, 2003-2015)

\author{
Mariano Dagatti ${ }^{1}$ \\ Universidad de Buenos Aires
}

\begin{abstract}
RESUMEN: Las retóricas políticas ofrecen una experiencia multisensorial de la política. Los estudios del discurso político, por lo tanto, no pueden limitarse a una descripción lingüística. Este artículo tiene por objetivo presentar los resultados de una investigación sobre los discursos públicos del llamado "Kirchnerismo", el partido de gobierno en la Argentina desde 2003 hasta 2015. Uno de los aspectos centrales de su identidad es la construcción de una retórica romántica, que envuelve sus diferentes perfomances discursivas: desde la oratoria, sus géneros, sus rituales, sus tópicos, hasta el despliegue de un mundo (audio)visual dominado por escenas y motivos iconográficos cuya filiación con la estética romántica puede demostrarse sin ambages. Los resultados indican que para la retórica romántica del Kirchnerismo la política es concebida como acto vital y autónomo, alimentado por ideas, convicciones, coraje y voluntad. Implica en cuanto a sus temas una exaltación de la patria o de la nación, una reivindicación de las causas del pueblo, entendido como colectivo y demandante soberano; la bendición de los liderazgos carismáticos, la celebración de ciertos valores trascendentales que exceden la mera gestión. Los rituales públicos preferidos del Kirchnerismo son los multitudinarios y envuelven, por lo general, una condición épica, con una fuerte carga adversativa. Imagina una democracia de alta intensidad. Las emociones son fundamentales. Con una perspectiva interdisciplinaria de trabajo, basada en la Retórica, la Semiótica y la Linguiística, esta comunicación pretende contribuir al debate sobre las retóricas políticas y de manera general sobre la relación entre análisis del discurso y lingüística.
\end{abstract}

Palabras-clave: Estudios Discursivos; Política; Kirchernsimo; Retórica romántica; Lingüística.

RESUMO: As retóricas políticas oferecem uma experiência multisensorial da política. Os estudos do discurso político, portanto, não podem limitar-se a uma descrição linguística. Este artigo tem como objetivo apresentar os resultados de uma investigação sobre os discursos públicos do chamado "Kirchnerismo", o partido que governou a Argentina de 2003 a 2015. Um dos aspectos centrais de sua identidade é a construção de uma retórica romântica, que envolve suas diferentes performances discursivas: desde a oratória, seus gêneros, seus rituais, seus tópicos, até a implantação de uma mundo (áudio)visual dominado por cenas e motivos iconográficos cuja filiação com a estética romântica pode se demonstrar inequivocadamente. Os resultados indicam que para a retórica romântica do Kirchnerismo a política é concebida como ato vital e autônomo, alimentado por

\footnotetext{
${ }^{1}$ Investigador asistente de CONICET/IESAC-UNQ, Profesor de Semiótica de los Medios de la Universidad de Buenos Aires. Doctor en Análisis del Discurso (FFyL, UBA).
} 
ideias, convicções, coragem e vontade. Implica em relação a seus temas uma exaltação da pátria ou da nação, uma reivindicação das causas do povo, entendido como coletivo e demandante soberano; a benção dos líderes carismáticos, a celebração de certos valores transcendentais que excedem a mera gestão. Os rituais públicos preferidos do Kirchnerismo são os multitudinários e envolvem, em geral, uma condição épica, com uma forte carga adversativa. Imagina uma democracia de alta intensidade. As emoções são fundamentais. Com uma perspectiva interdisciplinar de trabalho, baseada na Retórica, na Semiótica e na Linguística, este trabalho pretende contribuir para o debate sobre as retóricas políticas e, de maneira geral, sobre a relação entre análise do discurso e linguística.

Palavras-chave: Estudos Discursivos; Política; Kirchnerismo; Retórica romântica. Linguística.

ABSTRACT: Political rhetoric offers a multisensory experience of politics: we listen political speeches, we watch TV candidates talk, we participate in political rituals, we attend mobilizations and protests, we follow leaders in social media. Studies of political discourse, therefore, can't be limited to a linguistic description. The purpose of this article is to present the results of an investigation into the public discourses of the so-called "Kirchnerism", the left-wing ruling party in Argentina from 2003 to 2015. One of the central aspects of its identity is the construction of a romantic rhetoric, involves in its different discursive performances: from oratory, its genres, its rituals, its topics, to the unfolding of a (audio)visual world dominated by scenes and iconographic motifs whose affiliation with romantic aesthetics can be demonstrated unambiguously. The results indicate that for the romantic rhetoric of Kirchnerism politics is conceived as a vital and autonomous act, nourished by ideas, convictions, courage, will. It implies an exaltation of the country or of the nation, a vindication of the causes of the people, understood as collective sovereign; the blessing of charismatic leaderships, the celebration of certain transcendental values that go beyond mere management. The preferred public rituals of the Kirchnerism are the multitudinous ones and they usually involve an epic condition, with a strong adversative dimension. It imagines a democracy - and, therefore, a citizenship of high intensity. Emotions are indeed fundamental. From an interdisciplinary perspective of work, based on Rhetoric, Semiotics and Linguistics, this article aims to contribute to the debate on political rhetoric and in a general way on the relationship between discourse analysis and linguistics.

Keywords: Discourse Studies; Politics; Kirchnerism; Romantic Rhetoric; Linguistics. 
Los estudios discursivos estuvieron en sus orígenes marcados a fuego por los aportes de la lingüística. El proyecto del Ferdinand de Saussure de construir una disciplina orientada a estudiar "la vida de los signos en el seno de la vida social" cobró, medio siglo después, en los años del "giro lingüístico", una actualidad inusitada.

La Escuela Francesa de Análisis del Discurso, bastión fundamental en la configuración de la disciplina durante los años sesenta y setenta, tomaba por postulado la indisociabilidad de lengua e historia en el orden del discurso, utilizando una metodología que conjugaba la lingüística estructural, heredera del Curso de Lingüística General, con una "teoría de la ideología" de raíz marxista-lacaniano: el discurso era entendido como una de las formas materiales de la memoria histórica; el sujeto, otrora "fuente del sentido", era denunciado como "una ilusión", y el texto aparecía como una plenitud engañosa cuya “inconsistencia” fundamental el análisis debía revelar, enlazándolo con el "trabajo" de fuerzas inconscientes $^{2}$. El objetivo principal era "pensar la relación de lo ideológico y lo lingüístico evitando igualmente reducir el discurso al análisis de la lengua y disolver lo discursivo en lo ideológico"3.

La política - y específicamente, el discurso político - ha sido históricamente un objeto de estudio predilecto dentro del análisis del discurso. Esta predilección, vuelta evidente por la profusión de investigaciones sobre el tema, fue posiblemente el motivo de que el discurso político enseguida volviera notorios los límites de la descripción lingüística ${ }^{4}$ para dar cuenta de la experiencia política como fenómeno multisensorial.

\footnotetext{
${ }^{2}$ Para M. Pêcheux, el sujeto del discurso no se pertenece a sí mismo, se constituye "por el olvido" de aquello que lo determina. Como el barón de Münchhausen, que "se elevaba por los aires tirando de sus propios cabellos", un individuo es interpelado como sujeto de su discurso "por identificación (del sujeto) con la formación discursiva que lo domina", al estar sobredeterminado por preconstruidos ideológicos.

${ }^{3}$ La ideología fue objeto de múltiples definiciones por parte de autores tan diversos como K. Marx y F. Engels, R. Aron, L. Althusser, R. Boudon, E. Balibar, etc. Véase, por ejemplo, S. Žižek, Ideología. Un mapa de la cuestión. A pesar de las notables diferencias, en las décadas de 1960-1970 existía cierto consenso en cuanto a definir la ideología como "sistema global de interpretación del mundo social", dotado de "una existencia y un rol históricos en el seno de una sociedad dada". El concepto resultó decisivo para el análisis del discurso francés de los sesenta y setenta. L. Althusser desarrolla por entonces una teoría según la cual la ideología representa una relación imaginaria de los individuos con su existencia, que se concreta materialmente en aparatos y en prácticas. A su juicio, la ideología está ligada a lo inconsciente por el sesgo de la interpelación de los individuos como Sujetos: el sujeto como "efecto ideológico elemental". Por referencia a la vez al marxismo y a la teoría lacaniana de lo inconsciente, la mayoría de los fundadores del análisis del discurso "a la francesa" se inscriben en el marco de esta teoría.

${ }^{4}$ Los límites de la lingüística para estudiar diferentes fenómenos discursivos fueron notorios en diferentes dominios, desde aquellos artísticos como el cine y la pintura hasta aquellos comerciales como la publicidad. Sin embargo, se suponía que la política era el reino del logos, de la búsqueda de consensos racionales y, por lo tanto, de la palabra como materia significante. Tomamos aquí las palabras de C. Salavastru: "L'art de bien parler a trouvé dans le domaine de la politique le terrain le plus fertile pour sa manifestation. En tant qu'art d'organisation de la cité, de la societé en fonction de la distribution des relations de pouvoir, la politique s'est constituée comme un champ tout à fait ouvert pour la manifestation discursive de l'homme” (2004, p. 9).
} 
El mundo de la política involucra palabras, sonidos, imágenes, cuerpos, espacios. Ahora y siempre. Para Aristóteles la retórica, arte de la persuasión y por ende de lo común, estaba ligada de suyo a la política. Las cinco officia oratoris de la Retórica Antigua incluían, como fase constitutiva, la actio o pronuntiatio, que remitía sin ambages a la declamación del discurso. Gestualidad, variación de la voz, contacto visual con la audiencia, entonación y dicción oportunas resultaban todas destrezas ineludibles para una puesta en escena lograda. En De oratore, Cicerón exigía del orador, en las palabras de Craso, "la agudeza de los sofistas, la profundidad de los filósofos, poco menos que las palabras de un poeta, la memoria de un jurisconsulto, la voz de un tenor y casi los ademanes de los grandes actores" (I, 28, 128). Jean-Jacques Courtine y Carlos Piovezani han demostrado de manera convincente en su História da fala pública cómo los poderes del discurso se articulan con un cuerpo en acción. En "La palabra adversativa”, Eliseo Verón advertía, en el interior de una disciplina, la semiótica, que había girado excesivamente en torno a la lingüística, la necesidad de desarrollar una concepción encarnada de la política, que no analizara el discurso político como si fuera solamente un ente de palabra.

Con una perspectiva interdisciplinaria de trabajo, basada en la Retórica, la Semiótica y la Lingüística, este artículo expone resultados de una investigación sobre la retórica política del "Kirchnerismo", fuerza gobernante en la Argentina desde 2003 hasta 2015 . Parte de la hipótesis de que la configuración discursiva de la identidad kirchnerista estuvo regida por una retórica romántica ${ }^{6}$, que puede ser identificada tanto en el plano lingüístico como en el plano semiológico ${ }^{7}$. Pretende contribuir, de manera específica, al debate sobre las retóricas políticas, y, de manera general, a la reflexión sobre la articulación entre estudios discursivos y linguiística. Con vistas a la demostración de los argumentos, fueron considerados discursos orales monologales, afiches, spots de campaña y publicaciones en redes sociales digitales ${ }^{8}$.

El artículo está dividido en dos secciones. La primera sección explora la retórica romántica del kirchnerismo en el plano lingüístico; la segunda, en el plano semiológico. A los

\footnotetext{
${ }^{5}$ El kirchnerismo gobernó el país durante tres mandatos presidenciales consecutivos: primero, Néstor Kirchner: 2003-2007; después, Cristina Fernández de Kirchner: 2007-2015. En 2015, perdió en la segunda vuelta electoral contra la coalición de centro-derecha Cambiemos.

${ }^{6}$ Entendemos por retórica, de acuerdo con la definición de Marc Angenot, el estudio de la variación sociohistórica de los tipos de argumentación, de los medios de prueba y de los métodos de persuasión (2015, p. 91).

${ }^{7}$ No desconozco que los términos "lingüística" y "semiología" o "semiótica" remiten a disciplinas y campos de investigación específicos. Aquí no tienen más que un sentido operatorio ad-hoc: califico como "lingüístico" aquel plano en el que analizaré el lenguaje natural de discursos orales monologales y como "semiológico" aquel en el que analizaré lenguajes (audio)visuales.

${ }^{8}$ Los ejemplos son representativos de tendencias dominantes en la muestra. Ninguno de los argumentos pretende dar cuenta de todo el universo de imágenes creadas por estas fuerzas, que puede variar de acuerdo a diferentes contextos, estrategias, etc.; se trata, apenas, de concentrar la atención en rasgos habituales, recurrentes, que permiten, además, mostrar en toda su dimensión la retórica considerada.
} 
fines analíticos, la sección inicial está organizada en tres apartados: estrategias semánticoenunciativas, tópicos y dominante de $\operatorname{pathos}^{9}$. La segunda sección está centrada en las imágenes del kirchnerismo: fotografías de actos, afiches, frames de spots, posteos en redes.

\section{1. ¿De qué hablamos cuando hablamos de una retórica romántica? El plano linguiístico}

La retórica o matriz ${ }^{10}$ romántica opera en el plano lingüístico en tres niveles: el nivel semántico-enunciativo, el temático o tópico y el de las emociones. El primero de ellos considera el denominado "modelo de llegada", el tono o ánimo refundacional y la alegoría de los infiernos. El segundo expone los principales tópicos románticos: desde la celebración del coraje y los sueños hasta la confianza en la potencia creadora del sujeto. El tercero considera la indignación como forma de construcción de una escena política polarizada.

\section{1 "Más desocupados que votos": modelo de llegada, tono refundacional y alegoría}

Cuando asumió el cargo de Presidente de la Nación, Kirchner contaba en su balance electoral con el porcentaje de votos más bajo de la historia del país. El propio Kirchner solía decir que llegó al gobierno con "más desocupados que votos”. Era, para la mayoría de los argentinos, una incógnita: eran "pocos los que conocían su programa y aún su persona"

En efecto, los orígenes de la presidencia del santacruceño carecieron de esa filigrana de continuidad que, en una época signada por un abordaje más individualizado de las cuestiones políticas, es el pasado personal de la figura pública. ${ }^{12}$ La elipsis de su trayectoria, en este sentido, fue consustancial con un "modelo de llegada" que le daría al gobierno kirchnerista un impulso refundacional aún perceptible en la retórica de Cristina Fernández no sólo, ni principalmente, en los inicios de su gobierno, cuando el eslogan era la

\footnotetext{
${ }^{9}$ La noción está tomada de Angenot (2010).

${ }^{10}$ Por "matriz" hacemos referencia a la definición de "matriz discursiva" propuesta por Jean-Claude Beacco (2005). Ésta designa la suma de rasgos estructurales y enunciativos comunes o ampliamente compartidos propios de un conjunto de textos postulados entonces como tributarios de una misma maquinaria discursiva. Esto es, remite tanto a un espacio de regularidades generador de discursividad como a un molde que permite dar forma discursiva a datos diversos e, incluso, funcionar como grilla interpretativa de lo social. En este artículo utilizaremos indistintamente los términos "matriz" o "retórica", teniendo en cuenta la idea de gramáticas o maquinarias de producción de enunciados.

${ }^{11}$ Véase Cheresky (2006).

${ }^{12}$ Véase, a propósito del pasado biográfico y político de Kirchner, Curia, W. (2010).
} 
"profundización del cambio", sino en las semanas finales de su segunda presidencia, cuando la historia de la Argentina se dividía entre un antes y un después de Kirchner.

El modelo de llegada, como operación enunciativa, significa que el locutor construye en términos políticos "una distancia explícita entre sí mismo y sus destinatarios" "13, sea porque no pertenece en principio al campo político (es militar, es empresario, es deportista, etc. y se ve obligado a ingresar en pos del bienestar del conjunto) o porque no está ligado de manera directa a la situación de crisis que pretende resolver (estuvo proscripto, estuvo exiliado, estuvo enfermo, vivía afuera). En el caso de los Kirchner, la "llegada" estuvo ligada a dos pasajes complementarios, uno de índole espacial y otro temporal. Consideremos, primero, la llegada espacial, que incluye la entrada del orador desde el "Sur del mundo":

(1) Venimos desde el Sur del mundo y queremos fijar, junto a ustedes, los argentinos, prioridades nacionales y construir políticas de Estado a largo plazo para de esa manera crear futuro y generar tranquilidad. Sabemos a dónde vamos y sabemos a dónde no queremos ir o volver. (25 de mayo de 2003)

Esta entrada buscaba producir un efecto de exterioridad con la situación crítica del país y, sobre todo, con los dirigentes políticos responsables. El gobierno, según este esquema, asumía bajo su responsabilidad una realidad precedente y exterior, la de los argentinos, con la cual no tenía relación alguna. En su reivindicación del "Sur del Mundo", el modelo apelaba al lugar común de viejas dicotomías que habían definido históricamente el esqueleto de las ideas políticas de nuestro país: centralismo/federalismo, porteños/provincianos, ilustrados/plebeyos. Jugando con ellas, el "Sur" definía imaginariamente una geopolítica de la postergación y perfilaba un espacio de autoexilio interno, ligado a una semántica de la pureza y la incontaminación:

(2) Vienen aires fuertes del Sur, vientos del Sur para limpiar lo que haya que limpiar. (12 de junio de 2003)

El plano espacial de este "modelo de llegada", la llegada desde el "Sur", era reforzado por un plano temporal, el generacional: el de una militancia política postergada, la de los años setenta, que colocaba en primer plano la idea de recuperación de un proyecto nacional, relegada por la instalación y consolidación del neoliberalismo (1976-2001). Esta envolvía al kirchnerismo en el linaje de una epopeya histórica que atravesaba la historia argentina desde

\footnotetext{
${ }^{13}$ Véase Sigal y Verón (2004, p. 30).
} 
la Revolución de Mayo de 1810 hasta los años setenta del siglo XX. ${ }^{14}$ La postergación sureña dialogaba así con la postergación generacional, el exilio federal encontraba eco en el exilio generacional, y componían en conjunto formas gregarias del "nosotros":

(3) Formo parte de una generación diezmada, castigada con dolorosas ausencias; me sumé a las luchas políticas creyendo en valores y convicciones a las que no pienso dejar en la puerta de entrada de la Casa Rosada. [...] Soñé toda mi vida que éste, nuestro país, se podía cambiar para bien. Llegamos sin rencores, pero con memoria. Memoria no sólo de los errores y horrores del otro, sino también es memoria sobre nuestras propias equivocaciones. Memoria sin rencor que es aprendizaje político, balance histórico y desafío actual de gestión. ( 25 de mayo de 2003)

Kirchner se presentaba a sí mismo como un outsider político, que portaba en sus reclamos los estandartes de la causa federal y de las luchas generacionales. Sus relatos de la Patagonia y de la militancia setentista le conferían - como puede observarse en los parágrafos 4 y 5 - la clave de un relato romántico de iniciación, en el que se combinaban un conjunto de trazos de similar índole: desde una concepción soñadora de la política hasta la soledad del héroe, sin dejar de lado la experiencia subjetiva de dolor.

(4) Ustedes saben que solo puedo yo expresarles con todas las letras la angustia que me sumió el ver el estado deplorable que había quedado la Argentina. Sabía que estaba muy mal, pero yo venía desde el sur... (23 de junio de 2009)

(5) Yo les puedo asegurar que de aquel sueño que, siendo gobernador, tuve para llegar a la presidencia de la Argentina [...] Siempre me voy a acordar cuando recorría la Argentina del año 2002-2001, yo venía de una provincia que tenía sus necesidades básicas insatisfechas prácticamente solucionadas [...]; venía de un Sur que, con todo lo que sufría, siendo la parte trasera de Argentina, había compatibilización estructural [...]

Cuando juré el 25 de mayo de 2003, me quedé con mis pibes y la actual Presidenta; en ese despacho grande, $[\ldots]$ nos abrazamos fuertemente y les dije a mis hijos y a mi compañera de toda la vida y pensando en el viejo que ya no estaba, que no iba a dejar mis convicciones y mis principios de toda la vida, para tratar de durar de cualquier forma. [...] (10 de junio de 2009)

Con el lema del "cambio" como telón de fondo, el modelo de llegada del discurso kirchnerista se articulaba con el ánimo refundacional con que la fuerza gobernante dotó de potencia y de voluntad a su proyecto político:

(6) Pensamos el mundo en argentino, desde un modelo propio. Este proyecto nacional que expresamos, convoca a todos y cada uno de los ciudadanos argentinos y por encima y por fuera de los alineamientos partidarios a poner mano a la obra de este trabajo de refundar la patria.

\footnotetext{
${ }^{14}$ Sobre la cuestión de las tradiciones políticas, remitimos a Dagatti (2014).
} 
Sabemos que estamos ante un final de época; atrás quedó el tiempo de los líderes predestinados, los fundamentalistas, los mesiánicos. La Argentina contemporánea se deberá reconocer y refundar en la integración de tipos y grupos orgánicos con capacidad para la convocatoria transversal en el respeto por la diversidad y el cumplimiento de objetivos comunes. (25 de mayo de 2003)

La gramática discursiva de la «refundación» ${ }^{15}$ kirchnerista describía la crisis neoliberal como una situación infausta, cuyas víctimas habían sido los argentinos en general y los trabajadores en especial; designaba al neoliberalismo como la fuente del mal y a los gobiernos dictatoriales y democráticos del período 1976-2001 como sus responsables, y proponía como solución un «capitalismo nacional» que su administración habría de garantizar. Se trataba de una matriz repetida en diferentes oportunidades:

(7) El país se construye todos los días, apuntando hacia el conjunto de la sociedad, apuntando hacia una construcción de convivencia y alianza de las distintas clases sociales en la construcción de un proyecto nacional que nos contenga a todos [...].

Por eso, nosotros tenemos la firmeza y la convicción que hay que profundizar el cambio en la Argentina. Tenemos la firmeza y la convicción de seguir con todas nuestras fuerzas por ese cambio [...] a consolidar las políticas fundacionales que hemos tenido en esta etapa, estamos saliendo del infierno, si Dios quiere el 10 de diciembre de 2007 habremos salido del infierno. $[\ldots]$

El cambio recién empieza porque nosotros tuvimos que reconstruir una Argentina totalmente desarticulada, tuvimos que generar bases fundacionales y ahora viene fuertemente la profundización de ese cambio. ( 3 de julio de 2007c)

(8) Cuando allá por el 2003 vine a Bragado con algunos amigos aquí, a decirles de un sueño que teníamos de conducir la Argentina, algunos me miraban y decían: "y éste, quién es", era la realidad. Pero me recibieron en el Club con tanto cariño, con tanto afecto donde realizamos ese día el acto, me escucharon con tanta atención, que fue uno de esos días que sentí que desde un lugar a veces distinto, de crecimiento, de pelea por la idea por la nueva Argentina, se podía construir una nueva alternativa. [...]

Ustedes saben que la lucha por la construcción de la nueva Argentina tiene un alto grado de responsabilidad y madurez de todos nosotros. Tenemos que tener la fuerza de alcanzar banderas superadoras que nos contengan a todos. No nos debemos dejar llevar a luchas ridículas que la vieja dirigencia política sigue sosteniendo, por ver cuál o qué partido va a gobernar la Argentina, una provincia o una localidad. (29 de mayo de 2007b)

Los argumentos de "la construcción de la nueva Argentina" se caracterizaban por cuatro motivos persistentes, que atraviesan la totalidad del corpus analizado: primero, la impugnación típicamente romántica de la generación anterior (“la vieja dirigencia política”); también la apuesta por la conformación de un colectivo nacional transversal a las fronteras ideológicas o políticas ("proyecto nacional que nos contenga a todos", "banderas superadoras que los contengan a todos"); tercero, la presencia de un vocabulario romántico coloreado por

${ }^{15}$ Véase, a este respecto, el artículo de P. Charaudeau "Reflexiones para el análisis del discurso populista" (2009). 
sueños y luchas idealistas (la "pelea por la idea"), que se inscribían en el ethos militante del $\operatorname{orador}^{16}$; cuarto, la representación de la refundación como un tiempo amplio, gradual ${ }^{17}$, que la alegoría de la marcha nacional del "infierno" al "cielo" representaba en un relato patético a la vez familiar e hiperbólico.

A propósito de este motivo final, la alegoría del ascenso del infierno a los cielos era una constante que atravesaba los discursos de Néstor Kirchner como principal artefacto representativo de una refundación de índole gradual. Así, el final de su gobierno - y el comienzo del próximo - era definido por el orador como el pasaje del "infierno" al "purgatorio":

(9) Vamos a seguir avanzando y espero que el 10 de diciembre del 2007 desde alguna tarima le pueda decir al pueblo argentino "acabamos de salir del infierno, pasamos al purgatorio, hemos vencido la primera etapa los argentinos y se alumbran nuevos amaneceres sobre esta patria en que la justicia paulatinamente nuevamente vuelva a reinar". (20 de diciembre de 2006)

(10) A todos les digo que este punto de inflexión que tiene el país estoy seguro que marca que estamos en los últimos pasos del infierno y el 10 de diciembre de este año, por ahí le podemos decir al pueblo que estamos llegando al purgatorio. Y cuando lleguemos al purgatorio, necesariamente este país va a tener que entrar a discutir las bases de la Argentina estratégica [...] (30 de abril de 2007)

Esta "divina comedia" nacional se inscribía por lo general en una representación del pueblo argentino en marcha, que no necesariamente atencía al formato religioso, pero sí al formato de las narraciones épicas:

(11) Creamos fundamentalmente y con toda nuestra fuerza, con toda nuestra solidaridad, con las manos extendidas y tomándonos unos a los otros, que nos vea el mundo entero que los argentinos entramos a caminar las grandes avenidas de la patria, diciendo que estamos reconstruyendo la justicia, la equidad, la moral, la igualdad de una patria para todos. (15 de mayo de 2007)

(12) Yo creo mucho en ese 28 de octubre y les puedo asegurar que lo espero con una gran paciencia porque hay mucho que hacer, mucho que trabajar, pero sé que ese 28 de octubre los argentinos y las argentinas estaremos llegando a nuestras casas, después de haber cumplido nuestro deber cívico, sabiendo que le dijimos a la Argentina "seguí marchando". (22 de mayo de 2007b)

No hace falta una descripción exhaustiva para advertir una construcción enunciativa y semántica de la unidad nacional ("Creamos", "con toda nuestra fuerza”, "con toda nuestra

\footnotetext{
${ }^{16}$ Véase Dagatti (2017). Sobre el ethos militante, véase también Montero (2012).

${ }^{17}$ Ofrecemos un análisis detallado del gradualismo como construcción temporal del kirchnerismo en Dagatti (2013).
} 
solidaridad", "con las manos extendidas y tomándonos unos a los otros", "los argentinos", "una patria para todos", "los argentinos y las argentinas", "nuestro deber cívico", "le dijimos a la Argentina 'seguí marchando"') que dota a la figuración épica de un dispositivo a su medida. Los discursos de Kirchner exponían, pues, un modelo de llegada con ánimo fundacional cuyo carácter progresivo la alegoría épico-religiosa expresaba.

\subsection{Los tópicos románticos}

La retórica romántica se caracteriza por la activación de un conjunto de tópicos nutridos por el idealismo y el pathos, que refuerzan el dispositivo semántico-enunciativo descrito en el apartado precedente. Crisis, pérdida, tipos fundamentales, ideas, convicciones, soledad, dolor, sacrificio, esfuerzo, incomprensión son topoi que pueden ser reconocidos como típicos de una lógica argumentativa de índole romántica.

Comencemos por la crisis. El ánimo refundacional del orador entiende la "crisis"18 como la posibilidad de un nuevo comienzo, como una etapa prolífica para la creación de las ideas y pensamientos:

(13) Ya sabemos las sociedades del pensamiento único y uniforme donde terminan, yo prefiero las sociedades tensionadas, a veces en crisis, porque de las crisis del pensamiento, naturalmente, salen nuevas verdades contenedoras que nos permiten construir nuevos caminos, $\mathrm{y}$, evidentemente, una sociedad que no tiene referentes intelectuales y que no tiene referentes y pensadores que la ayuden a orientarse hacia dónde vamos, es muy difícil que tenga y se pueda orientar en el futuro que la Argentina necesita. (20 de junio de 2007)

Como corresponde a una matriz romántica de pensamiento, el carácter épico de la refundación se articula con una metáfora de la pérdida, la privación o la postergación y, por ende, con una "psicología de la insatisfacción"19 de índole generacional:

(14) Señor Vicepresidente, querido amigo Daniel; gobernador, querido amigo Felipe; señor Intendente de Lanús, querido amigo Manolo; empresarios, amigos, vecinos de Lanús: somos dos generaciones que nos cruzamos en el tiempo y en la historia, nos tocaron vivir momentos felices y momentos tristes en el país. Manolo tuvo la suerte de vivir aquellos momentos felices de Perón y de Evita; yo tuve la suerte de estar en el "luche y vuelve" de Juan Domingo Perón, él también, estuvo en las dos etapas. Ambos somos de generaciones que pensamos en la construcción de un país que se nos escapó de la manos, porque lamentablemente sucedió lo que todos sabemos y que no queremos que vuelva a suceder nunca más, la intolerancia, el menosprecio a la voluntad popular, el desprecio por la voluntad del sentimiento popular en la Argentina, el sentimiento nacional, el desprecio al sentir de

\footnotetext{
${ }^{18}$ Sobre la concepción de la crisis en el ideario romántico, véase Barthes (2004).

${ }^{19}$ Sobre la psicología de la insatisfacción en el romanticismo, véase Altamirano y Sarlo (1997).
} 
Patria, el desprecio al sentir de justicia, el desprecio a la alianza policlasista entre trabajadores, clase media, empresariado nacional. (8 de mayo de 2007b)

La última dictadura militar y, en términos más amplios, la política neoliberal, son juzgados por Kirchner como procesos de privación de un poder que como generación hubieran debido ejercer sobre la base de una razón doble: sus ideas y su juventud. La frustración generacional - e incluso intergeneracional - por "La construcción de un país que se nos escapó de las manos" ostenta la idea de pérdida, de caída, de privación de una herencia que el orador despliega desde su discurso inaugural ante la Asamblea Legislativa cuando dejó entrever que sus sueños eran la encarnación de otros sueños:

(15) Vengo, en cambio, a proponerles un sueño: reconstruir nuestra propia identidad como pueblo y como Nación; vengo a proponerles un sueño que es la construcción de la verdad y la Justicia; vengo a proponerles un sueño que es el de volver a tener una Argentina con todos y para todos. Les vengo a proponer que recordemos los sueños de nuestros patriotas fundadores $y$ de nuestros abuelos inmigrantes $y$ pioneros, de nuestra generación que puso todo y dejó todo pensando en un país de iguales. Pero sé y estoy convencido de que en esta simbiosis histórica vamos a encontrar el país que nos merecemos los argentinos. (25 de mayo de 2003)

Esta desposesión, esta pérdida, es un límite considerado ilegítimo e injusto; de allí una psicología de la insatisfacción que se relaciona con el deseo de producir aquello que precisamente falta: una identidad nacional, una unidad, "una Argentina estratégica". Para ello, inscripto en una concepción romántica, el orador no hace sino potenciar una teoría de la historia nacional pensada a través de sus tipos fundamentales; un linaje de grandes nombres que culmina en el proyecto propio:

(16) Estamos saliendo del infierno, generamos las políticas fundacionales para ello. Yo estoy seguro que los tiempos que vienen serán los de la creación de la nueva institucionalidad en el país y que la Argentina alumbrará con fuerza en el mundo y también para adentro porque a nosotros, como siempre decimos, nos interesa un país integrado al mundo, pero nos interesa un país integrado en lo interno. Queremos que los argentinos volvamos a sentir que la bandera de nuestra Patria nos protege a todos. [...] Nosotros queremos una Argentina libertaria, esa que soñaron próceres como Mariano Moreno, como San Martín, como el General Belgrano, como Irigoyen. Como yo siempre digo, respetando todas las ideologías, pero que siempre lo digo con el mayor de mis sentimientos, porque es lo que ha inspirado, muchas veces, esa rebeldía y esa posibilidad de ir a luchar por causas que algunos consideraban perdidas y nosotros no, siempre esa capacidad transgresora de decisión de construir un futuro mucho más digno y más justo que dejó esa mujer que simplemente se llamó Evita y que yo la quiero recordar en esta embajada con todas las fuerzas. (2 de agosto de 2007) 
“Expresivismo holístico”, según la definición de Terán: “"un grande hombre’ expresa una época" ${ }^{20}$. La confluencia en la oratoria de Kirchner de los deseos, sueños y acciones de los próceres patrios, de los grandes líderes y del gobierno del que forma parte llama la atención sobre una concepción de las grandes figuras patrias como representantes generales de la sociedad, como partes representativas del todo, como seres que encarnan, de una manera casi mística, la voluntad general. "La nación se concentra en ellos", explicaba Hegel en su Estética, "se encarna en un individuo" y añadía que "Estos personajes son naturalezas completas que resumen en ellas su brillo lo que se encuentra disperso y diseminado en el carácter nacional”. Como afirma Scavino, "La figura del hêgêmôn, del líder, del conductor, resulta inseparable de la 'epopeya histórica de un pueblo' o de una 'gesta popular", 21.

Tono refundacional, alegoría del pueblo en marcha, sensación de pérdida, euforia de la crisis, tipos fundamentales; el carácter romántico del orador se encarna también en una subjetividad política marcada, como las del militante y el trabajador, por la potencia de las ideas, los sueños y las convicciones, y por el coraje y el sacrificio:

(17) A partir de allí, comenzamos con esta loca idea para algunos de intentar cambiar la relación de fuerzas en la Argentina y animarnos, con coraje, a construir un proyecto distinto, un proyecto que contuviera a todos los argentinos. (19 de mayo de 2007)

(18) Nosotros creemos en los sueños, en las esperanzas, en el amor, en la convivencia. No creemos en la descalificación, en el agravio, en la patoteada en una Argentina que sufrió tanto. Pero ¿qué van a hacer, nos van a pegar, nos van a matar, nos van a asesinar? Pero no van a quebrar nuestras ideas bajo ningún aspecto, porque las ideas son inalterables y tienen la fortaleza de la verdad y de la moral. (2 de julio de 2008)

(19) Por eso, queridos hermanos y hermanas, vale la pena luchar y pelear por un nuevo país. No importan los costos, no importan los sacrificios, importan las ideas, las convicciones, la decisión de hacerlas. (9 de marzo de 2009)

Guiado por el coraje y los sueños, el sujeto romántico confía en la voluntad y potencia ilimitada de la expresión creadora. La ética de la convicción se impone a la de la responsabilidad. Un político de esta índole se concibe a sí mismo como una "fuerza moral redentora" capaz de empezar siempre "de nuevo". En una relación de amor y compañía con el pueblo, el sentimiento de soledad del líder, su heroicidad, su fuerza, su protagonismo son destacadas:

\footnotetext{
${ }^{20}$ Véase Terán, 2009, p. 70.

${ }^{21}$ Véase Scavino, 2012, pp. 182-183.
} 
(20) Pero lo bueno de caminar, de tocarnos las manos, de saludarnos, de darnos fuerzas, de escuchar lo que la gente nos dice, es que nos da una fuerza espiritual tremenda. Les puedo asegurar que ustedes hoy en Coronel Suárez nos han hecho vibrar fuertemente. Hay muchas veces que en la soledad, cuando se vienen todos los intereses encima, uno tiene que ponerse firme, tiene que ponerse con toda esa potencia que tenemos los argentinos de creer en nosotros mismos. Pero yo sabía, Cristina, lo viste y lo ves en cada pueblo, estuvimos en San Juan, en Bragado, en Arrecife, en Alberdi, donde vamos, en todos esos lugares donde hemos estado últimamente he notado que a veces uno creía que estaba luchando solo, pero estaba luchando con todos ustedes y cada uno me acompañaba de su casa, de su trabajo, dándome las fuerzas que correspondía. (7 de junio de 2007b)

(21) No importa Cristina, no importa Presidenta, acá estamos los que creemos que en la vida no vale la pena llegar a algún lugar o ganar una elección o tratar de ir acomodándose el cuerpo de acuerdo con los intereses. Los que estamos acá venimos a dar testimonio de una absoluta convencimiento con los principios [...] venimos a consolidar un proyecto nacional y popular, que hoy usted conduce y que nosotros apoyamos con todas nuestras fuerzas en su profundización, compañera Presidenta coraje, que no le aflojó en un minuto, y yo que la conozco de tanto tiempo y la amo tanto, sé que va estar con la bandera, adelante, conduciéndonos a los argentinos hacia mejores tiempos. (25 de junio de 2009)

De la transferencia de fuerzas del pueblo a los líderes en el extracto 20 a la hipotiposis con reminiscencias románticas del extracto 21, en el que, según la vívida imagen, Cristina está guiando al pueblo, una interacción permanente, una circulación de energía define el vínculo entre los representantes y los representados. Sensibilidad legítima, esta energía, este contacto, esta proximidad del pueblo se convierte en la razón de la lucha de una subjetividad por lo demás sufriente, agobiada, que aunque alegre y feliz en su presente, guarda los rastros de un pasado doliente:

(22) Nosotros nunca vamos a ser cultores del rencor, nunca vamos a predicar el odio entre argentinos, nunca vamos a descalificar al que piensa diferente porque sabemos y sufrimos en carne propia [...] Pero nosotros, que sufrimos tanto, tenemos que ser el punto de inflexión y saber convivir en democracia en diferencia. $Y$ aún aquellos que han estado agresivos, y aún aquellos que nos agravian y nos insultan, y aún aquellos que reaccionan con una violencia inusitada porque solamente defendemos la mesa de los argentinos donde comen nuestros hermanos y hermanas, nosotros igual le abrimos los brazos con comprensión, con amor y con cariño porque queremos hacer una patria con todos y para todos aún en la diferencia y lo que vale son los sueños, el amor. (1 de julio de 2007)

En una matriz romántica, el sentimiento del dolor, como sucede con la experiencia de una crisis, se convierte en núcleo de producción, en motor de la acción, en la base de surgimiento del coraje, en una prueba de una subjetividad por lo demás marcada por el sacrificio, el esfuerzo y la solidaridad:

(23) [...] vengo de una provincia donde la pobreza es la más baja del país y acá todavía miren lo que tenemos que luchar que a pesar de todo lo que hemos hecho en forma conjunta en 
Chaco, los índices de pobreza todavía nos duelen tremendamente y los tenemos que bajar con esfuerzo, sacrificio y solidaridad entre todos. Este Norte Argentino lo conocí de la mano de muchos de ustedes. Me encontré con un país, parte de un país junto con el Conurbano que fue de los más agredidos por la crisis, pero nunca vi un chaqueño con los brazos abajo, siempre fuerte, adelante por una Argentina integrada, siempre vi a los chaqueños abrazados a la patria, siempre vi a los chaqueños con esperanza. (15 de mayo de 2007)

(24) No saben lo que yo sufría en las mañanas del 2003, allá por mayo y junio cuando llegaban las misiones del Fondo a decir como teníamos que hambrear a los argentinos; no nos venían a decir cómo teníamos que salir, sino cómo teníamos que seguir dependiendo. (26 de junio de 2007)

Típico tópico romántico, la sociedad, sus adversarios, incluso sus compañeros o pares, parecen por momentos incapaces de comprender lo que el sujeto produce, lo que busca, lo que desea. Por caso, en el extracto 25:

(25) Nos miraban y nos decían que si seguíamos con las políticas que teníamos solamente iba a haber un efecto rebote, que íbamos a crecer un año y después nos íbamos a caer de vuelta, los mismos que quebraron y fundieron el país o los mismos que se llevaron sus riquezas afuera. Hace 4 años y entramos en el quinto año de crecimiento consecutivo, no recuerda la historia argentina, 5 años de crecimiento a este nivel, ¿dónde están los que decían que era el efecto rebote? Por qué no se dan cuenta que hay un verdadero cambio definitivo en el país. (5 de junio de 2007b)

La interrogación retórica que cierra el extracto 25 da por descontado el "verdadero cambio definitivo en el país", al tiempo que convierte a la evidencia del cambio en un motivo de peso para enfatizar el pedido de comprensión. En el fragmento 26, el tópico de la incomprensión permite articular la evidencia del modelo neoliberal del adversario con su convicción de que no está siendo lo suficientemente claro en su afán por exponerlo:

(26) ¿Cuánto costará el boleto de ferrocarril si pretende electrificar las distintas líneas, como dice, desarrollar todos los pasos a nivel necesarios para mejorar la frecuencia de los mismos? ¿Lo plantea desarrollar bajo las leyes del mercado, eliminando los subsidios que tanto critica? Acá intendentes bonaerenses estén atentos ustedes también, ¿cuánto van a tener que pagar? [...] Venimos de menos cero, estamos tratando de subir, tratando de mejorar, hemos mandado una nueva ley, todo el mundo sabe lo que estamos haciendo, ¿pero se imaginan cómo va a hacer todas estas inversiones con el déficit que tiene el presupuesto? Salvo que quiera echar gente, bajar costos por otros lados, pero, presupuestariamente ¿cómo va a hacer? ¿Por qué todos ustedes, los que están en las casas no pueden analizar estas cosas? (6 de junio de 2007b)

Tratemos de reunir los elementos: al modelo de llegada, al tono refundacional, a la metáfora de la pérdida, a los tipos fundamentales, es preciso sumarle los rasgos de una subjetividad patética atravesada por sueños, ideas y convicciones. La matriz romántica 
impone un registro oratorio dominado por "el ámbito de las emociones" ${ }^{22}$. No parece desacertado sugerir, como lo hace Parret, que lo pasional resulta "la única posibilidad de toda realización intersubjetivamente eficaz"23.

\subsection{La retórica de la indignación: la compasión refractada}

La matriz romántica implica "un viraje hacia la propia subjetividad", una "exaltación del yo", cuyo horizonte es la expresión de una "vida interior" auténtica, que se manifiesta en una argumentación desordenada y espontánea.

No debería sorprender, por ello, que la indignación ocupe un lugar destacado en la oratoria de Kirchner. Ya Beatriz Sarlo, en La audacia y el cálculo, había afirmado que "la única forma retórica afín a las cualidades espontáneas de Néstor Kirchner fue la indignatio, destinada según Cicerón a "concitar gran odio y sentido de la ofensa""24. Para la autora, el santacruceño "no fue el primer presidente peronista que recurrió a la indignatio. Pero fue el primero que la puso como género dominante, como si no pudiera tocar otras cuerdas ni otros tonos afectivos" 25 .

Con máximo rendimiento ante los discursos de masas, la indignación es, según Aristóteles, hermana de la compasión, "pues a la pena originada por las adversidades inmerecidas se opone en cierta manera, y procede de la misma disposición de espíritu, la pena causada por las prosperidades inmerecidas": son sentimientos "propios de un carácter honesto, pues debe uno condolerse y compadecerse de los que son desgraciados sin merecerlo e indignarse contra los que son injustamente felices" ${ }^{26}$.

"Querer ahogar en sí toda simiente de cólera no es sino una fanfarronada estoica" 27 . La frase de Bacon que recuerda Barthes da cuenta de una moral de la mesura a la que el orador indignado se enfrenta con sus signos de inflación: enfática, la indignatio se articula en Kirchner con la mencionada matriz romántica de renovación generacional. La degradación moral y cultural de la situación a la que el orador arriba o las manifestaciones opositoras de los adversarios son, por ello, denunciadas con todos los recursos que la retórica presta a la indignación. Citemos un único y largo fragmento:

\footnotetext{
22 Véase Terán, 2009, p. 69.

${ }^{23}$ Véase Parret, 1995, p. 11.

${ }^{24}$ Véase Sarlo, 2011, p. 138.

${ }^{25}$ Ibídem, p. 139.

${ }^{26}$ ARISTÓTELES, El arte de la retórica, op. cit., pág. 184. Véase Aristóteles, 2005, p. 184.

${ }^{27}$ Véase Barthes, 2004, p. 125.
} 
(27) Dijo bien el gobernador Solá; en agosto de 2003 anunciamos las 4 plantas; está acá la primera terminada, 75 millones de pesos de inversión. ¿Claro! para algunos economistas y para algunos comentadores de la realidad, esto significa que se incrementa el gasto público en la Argentina. ¿Claro! Ellos tienen agua, cloacas, todos los servicios, tendrían que venir acá a Hurlingham que hasta hoy tenían cero por ciento de cloacas [...] Esto no es gasto público, esto es inversión pública [...] Escúchenme, empezamos la obra en agosto de 2003; según ellos no tendríamos que hacer ninguna obra porque todo es gasto electoral. ¿Qué problema tienen con este tema de lo electoral? Los veo tan preocupados. [...] ¿Qué problema tienen? Ellos tienen la suerte que nunca van a elecciones; ellos pueden escribir bien, mal, lo que venga, qué importa si con el dueño o el patrón que tienen y si escriben de acuerdo a lo que ellos quieren - la mayoría de ellos, no todos por supuesto - no tienen problemas. [...]

¿Por qué esta manía? Yo no sé si porque vengo de un pueblo chico, si vengo del país federal como vienen todos ustedes que son acá parte de la provincia de Buenos Aires, a algunos los pone tan nerviosos. Han administrado el país durante años, han administrado el país pensando con un concepto totalmente centralista $\mathbf{y}$ fue absolutamente doloroso $\mathbf{y}$ desastroso lo que nos pasó.

¿Por qué no nos dejan trabajar? ¿Por qué no nos apoyan seriamente para trabajar con un espíritu constructivo? ¿Por qué esta manera de creerse que se es buen periodista si se habla mal, se agravia y se descalifica?

[...] No me van a presionar mediáticamente. No, porque me voy a abrazar a mi pueblo y junto con mi pueblo vamos a construir la Argentina que nos merecemos. (10 de abril de 2007)

Exclamaciones (“¡Claro!”), interrogaciones (“¿Qué problema tienen con este tema de lo electoral?”, “¿Por qué esta manía?”), incluso en estructura anafórica (“¿Por qué no nos dejan trabajar? ¿Por qué... y se descalifica?”) o acompañadas por provocación (“¿Qué problema tienen... Los veo tan preocupados"); imperativos ("Escúchenme”), mimesis ("lo que venga, qué importa"), hipérbole ("cero por ciento"), negaciones ("Esto no es gasto público", "No me van a presionar mediáticamente"), tópicos patéticos de antinomia Buenos Aires / interior ("Yo no sé si porque vengo de un pueblo chico, si vengo del país federal...", "Han administrado... un concepto totalmente centralista"), imprecisiones y subjetivemas peyorativos ("algunos... comentadores de la realidad"): la sucesión de recursos retóricos se estructuran en una polarización respecto de los poderosos y las elites ("ellos tienen agua, cloacas", "Ellos tienen la suerte...") y en una solidaridad respecto del pueblo ("me voy a abrazar con mi pueblo... y junto a...”). Compasión e indignación son dos caras de un mismo proceso de comunión popular y de antagonismo con los poderosos. ${ }^{28}$

\footnotetext{
${ }^{28}$ Aristóteles señaló: "Son propensos a la indignación los que fueren dignos de grandes bienes y estuvieren en posesión de ellos, porque no es justo que los que no son semejantes a éstos, sean juzgados dignos de tales bienes. En segundo lugar, los que fueren honestos y virtuosos, porque juzgan correctamente y odian lo injusto. [...] Y en general, los que se tienen a sí mismos por dignos de aquellas cosas de las cuales se juzgan dignos a los demás, son propensos a la indignación contra ellos y por estas razones. Por eso, los que tienen un carácter servil, bajo y sin ambición, no son propensos a la indignación, pues no existe nada de lo cual se juzguen dignos a sí mismos" (2005, p. 187).
} 


\section{El plano semiológico}

La retórica visual del kirchnerismo es convergente con la matriz romántica de los discursos kirchneristas. Comparada con otros imaginarios políticos ${ }^{29}$, resulta más clásica, más tradicional, y se define por una exaltación de la política como acto vital y autónomo, alimentado por las convicciones, el coraje y la voluntad. Apela a formas de imaginar la política que tuvieron una intensa vida en el siglo XX y de las cuales no escaparon movimientos tan diversos como el fascismo italiano o el socialismo francés, o en la Argentina el radicalismo, el comunismo y el peronismo. El "giro a la izquierda" en América Latina alimentó imaginarios de similar índole en Brasil, Venezuela, Ecuador y Bolivia, aun cuando sus características efectivas hayan sido diferentes. [Fig. 1, 2 y 3]

Figura 1

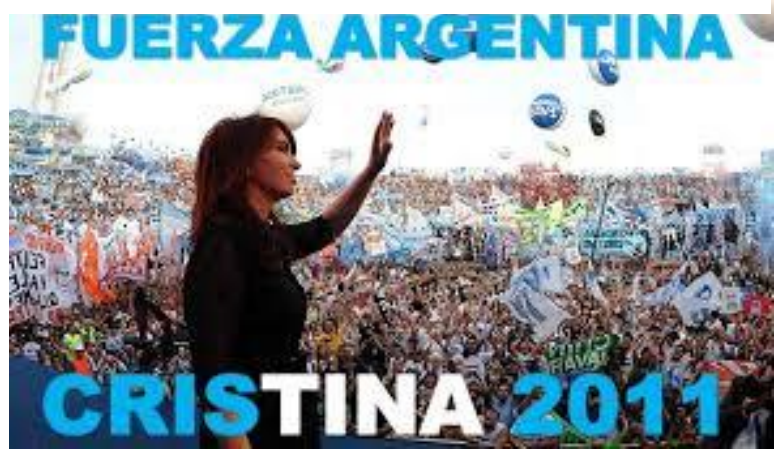

Figura 2

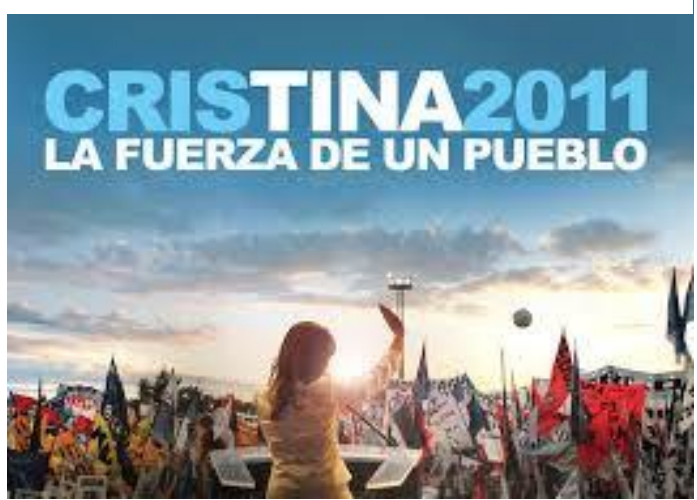

Figura 3

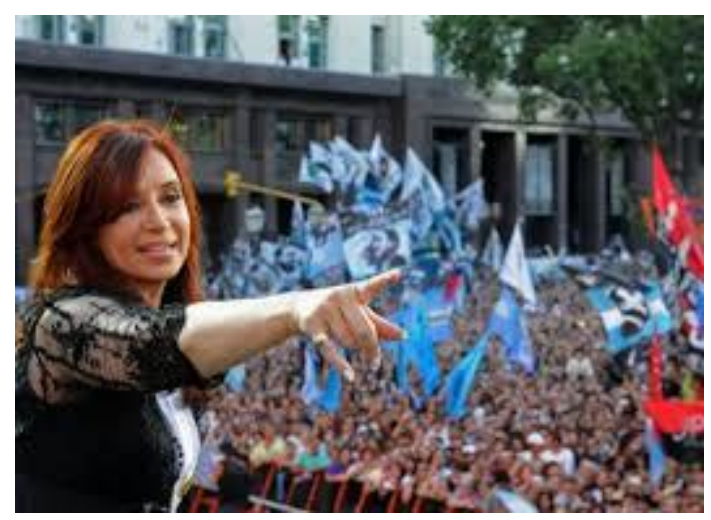

${ }^{29}$ Véase Dagatti, M. (2017). 
La retórica romántica del kirchnerismo implicaría en cuanto a sus temas una exaltación de la patria y de la nación, una reivindicación de las causas del pueblo, entendido como colectivo y demandante soberano; la bendición de los liderazgos carismáticos, la celebración de ciertos valores trascendentales (para esta fuerza, la política excede invariablemente la mera gestión, se trata casi siempre de una gesta).

A menudo se ofrece una visión tan colectiva y multitudinaria como jerárquica de la política; en este sentido, los encuadres de sus filmaciones o de sus afiches parecen conminados a la panorámica, al plano amplio, que puede coexistir con primeros planos si estos sugieren emociones inefables, la trama de un sentimiento de pertenencia o la expresión de una structure of feeling. Sus rituales públicos preferidos son los multitudinarios y envuelven, por lo general, una condición épica, con una fuerte carga adversativa: son verdaderos "rituales de enfrentamiento", si tomamos la aserción de Marc Abélès en El espectáculo del poder. La política es concebida - y sobre todo imaginada - como una praxis vital y autónoma, intensa, apoteósica. Se trata - recordemos algunas frases muy escuchadas o leídas - de "dejar la vida por la política", de "insistir ante la adversidad", "de no renunciar a las ideas", de imaginarse la política dominada por eso que Barthes llamaba en "Fotogenia electoral" "la tiranía del ideal". [Fig. 4 y 5]

Figura 5

Figura 4
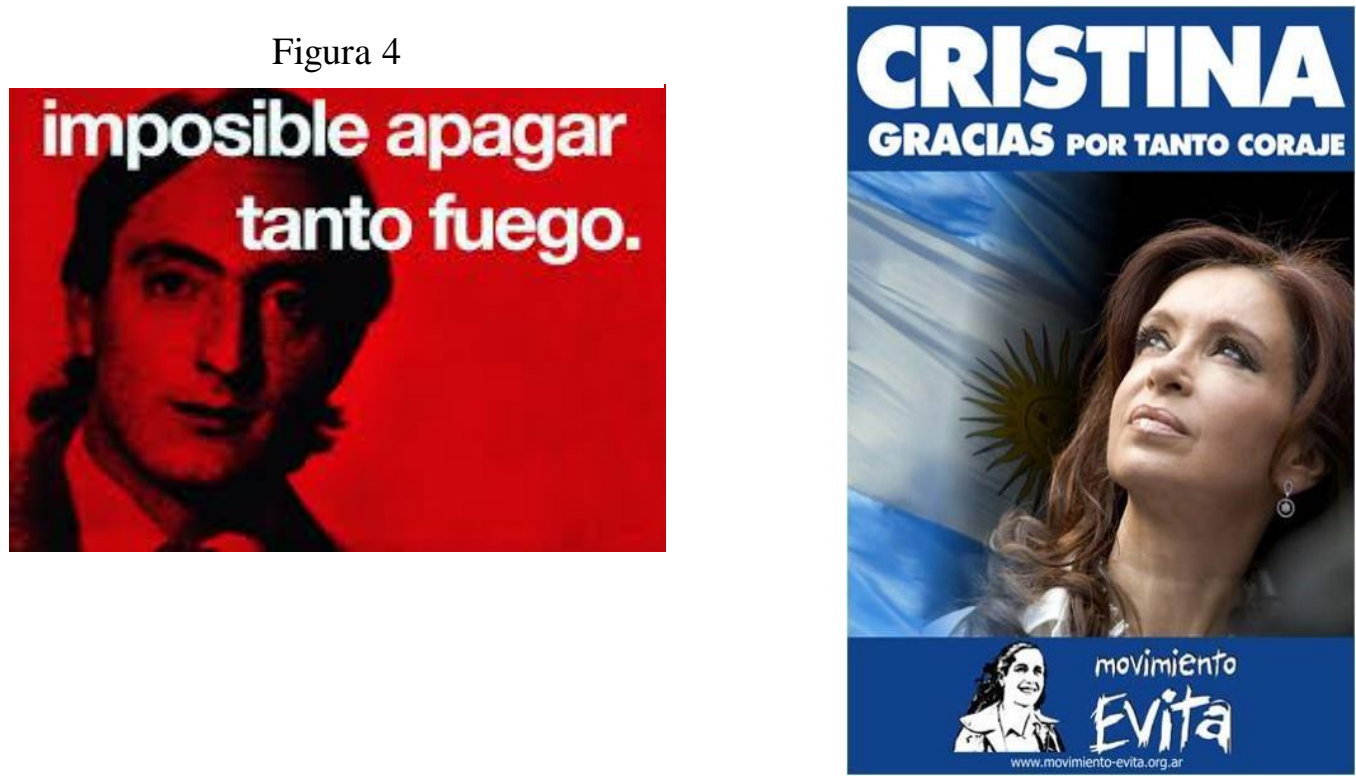

La retórica romántica pone en escena relaciones que podríamos llamar con Gregory Bateson "de complementariedad": liderazgos fuertes, matrices pedagógicas de transmisión de valores, sea para la militancia juvenil, que asegura la transmisión intergeneracional, o sea para 
el pueblo en su conjunto, que debe saber de qué se trata. No casualmente la zona del saber ocupa áreas importantes de la retórica del líder ${ }^{30}$. [Fig. 6 y 7]

Figura 6

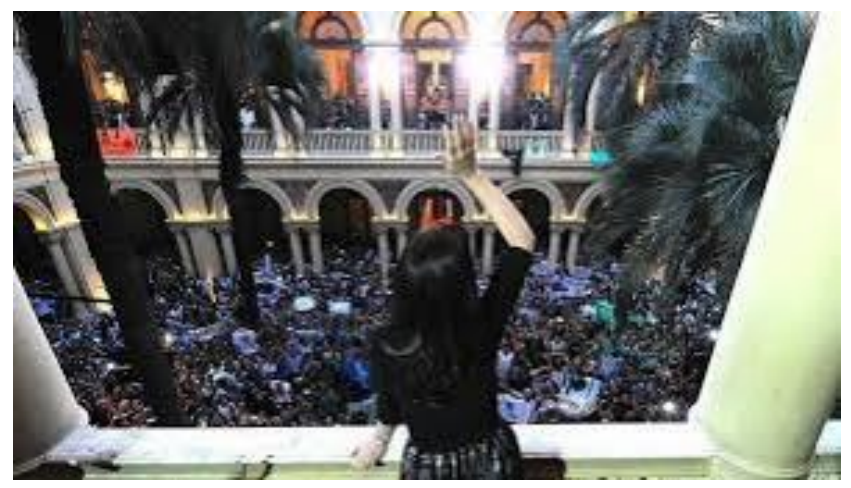

Figura 7

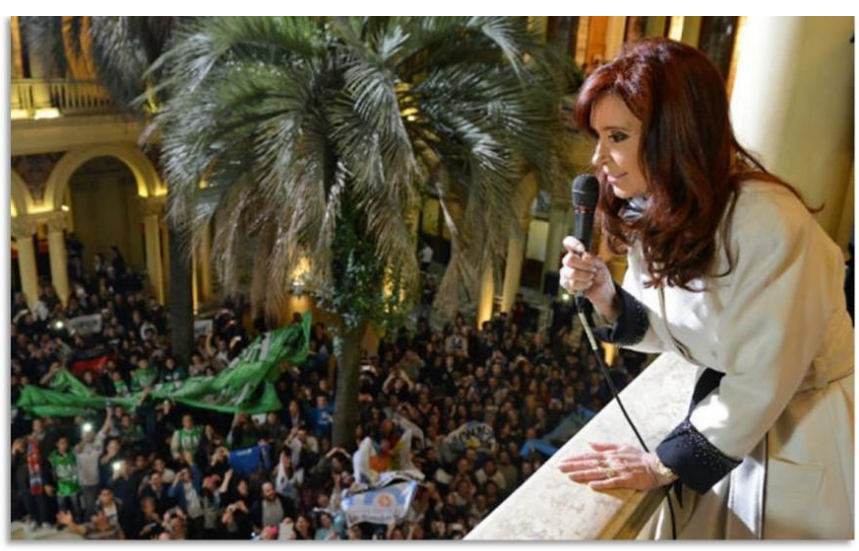

La retórica romántica sugiere una ética de la híper-politización: la política implica una praxis excepcional, autónoma, cuyos contornos respecto a la vida cotidiana, a los hábitos y a las costumbres aparecen a menudo tallados con pulso firme. Imagina una democracia - y, por lo tanto, una ciudadanía - de alta intensidad. Subordina, relega la representación política de los espacios privados, considerados secundarios o ajenos a las dinámicas políticas; incluso en las redes sociales digitales, en las que la ostentación de lo privado es regla y no excepción. Su imaginación política es mayormente épica, no doméstica; multitudinaria, no individual. [Fig. $8,9$ y 10$]$

\footnotetext{
${ }^{30}$ Sobre el saber en los discursos de Cristina Fernández de Kirchner, véase, por ejemplo, Vitale, M. A. (2013): "Ethos y legitimación política en los discursos de asunción de la presidente argentina Cristina Fernández de Kirchner", en revista Icono, 14, volumen 11 (1), pp. 5-25.
} 
Figura 8

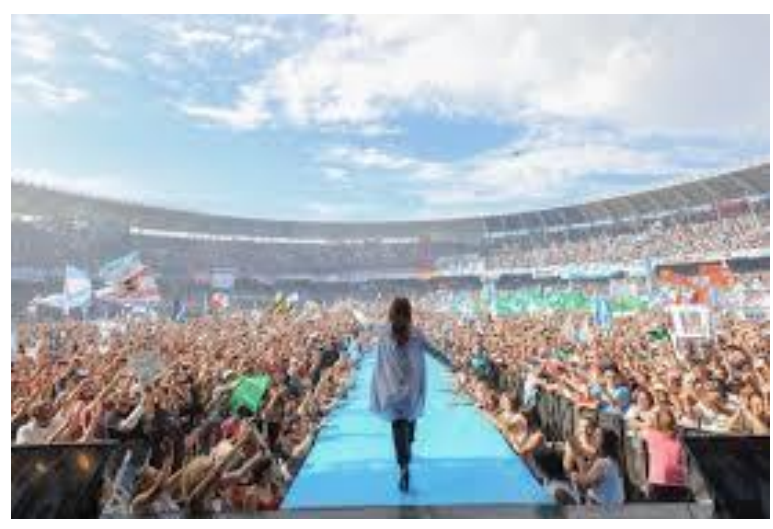

Figura 9

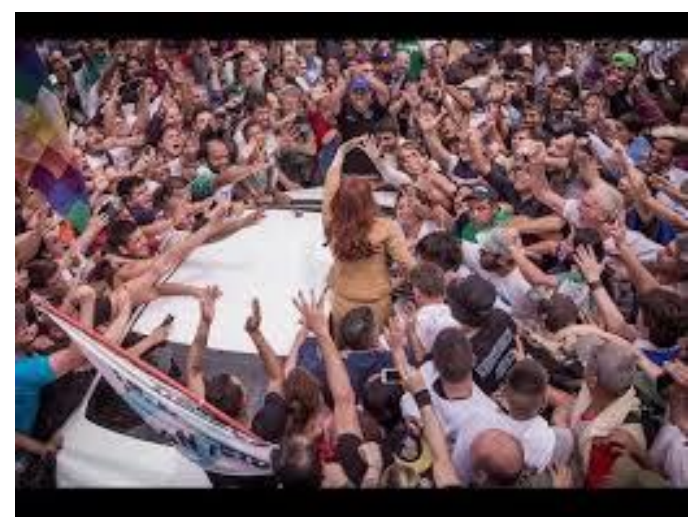

Figura 10

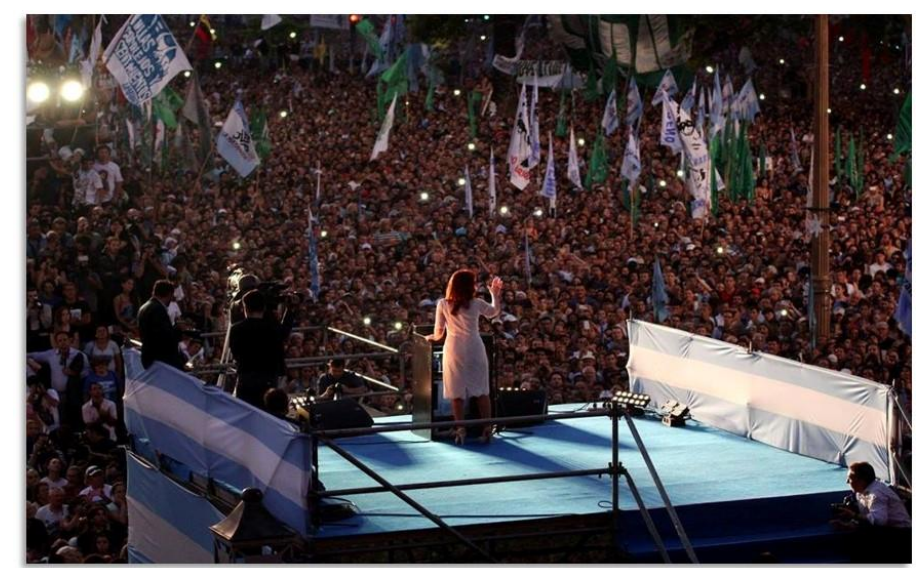

El sistema de imágenes que acabo de describir no agota, por supuesto, la imaginación política del kirchnerismo, pero ofrece pistas sobre la posición de dicha fuerza política en el escenario político argentino y latinoamericano.

Cuando se consideran simultáneamente los planos lingüístico y semiológico, es posible percibir que la imaginación romántica del kirchnerismo es convergente con el imaginario que sus palabras despliegan. El mundo ético del kirchnerismo implica palabras, imágenes, sonidos, rituales, que configuran en conjunto un colectivo de identificación, con sus memorias discursivas, semiológicas, comunicacionales. 


\section{Conclusiones}

Estudiar fenómenos de sentido implica considerar la articulación entre las diferentes ciencias del sentido - desde la retórica hasta la semiótica, pasando por la argumentación, la lingüística, la semántica - y entre estas y las ciencias sociales y naturales.

Entiendo al análisis del discurso como un ámbito interdisciplinario cuyo objetivo es estudiar los diferentes planos significantes de las materias discursivas con las herramientas provistas por el conjunto de las ciencias mencionadas, conforme a la construcción de los objetos de investigación y a la relación dialéctica que el investigador mantiene con ellos y los marcos teórico-metodológicos de referencia. Los alcances de la interdisciplinariedad dependen de los objetos de investigación, no de un a priori epistemológico.

Los estudios discursivos estuvieron al principio guiados por la confianza en el carácter científico de la lingüística, pero los modelos inspirados en ella mostraron tempranamente sus logros y sobre todo sus límites. Hoy en día, nuestra tarea como analistas del discurso es tender a la convergencia de las disciplinas, porque los fenómenos significantes presentan habitualmente múltiples caras y son el resultado de la confluencia de materialidades diversas. No parece aventurado suponer que el estudio de estas nos conduzca a nuevos desafíos, en virtud de las posibles convergencias o divergencias de los sentidos producidos en diferentes planos.

Mi propósito en este artículo fue ofrecer a los lectores el análisis de un caso en el ámbito del discurso político. Consideré los discursos públicos del kirchnerismo, a partir de un conjunto vasto de materiales de archivo que involucraban palabras e imágenes. Analicé aspectos temáticos, retóricos y enunciativos tanto en el plano lingüístico como en el plano (audio)visual. Demostré la presencia en ellos de una retórica romántica ${ }^{31}$, que celebra los sueños, las ideas, las convicciones, que celebra las multitudes y los liderazgos, que confía en el poder de la voluntad para cambiar un estado de cosas, que encuentra en la indignación un motor de producción de enunciados. Es una concepción de la práctica política que se alimenta en buena medida de tradiciones políticas que vivieron su auge durante el siglo $\mathrm{XX}$, pero que conservan su fuerza en la actualidad y encuentran a menudo eficacia interpelativa.

La persistencia de estas tradiciones - y, por lo tanto, la posición que ellas ocupan dentro del tablero político de cada sociedad - deben ser analizadas a la luz de una mutación del campo político y de la relación entre política, medios de comunicación y ciudadanía. Me

\footnotetext{
${ }^{31}$ No digo que la retórica romántica agote la productividad discursiva del kirchnerismo. De hecho, he demostrado cómo conviven allí otras perspectivas.
} 
refiero a ciertos imaginarios de la política que cobraron centralidad a partir del cambio de siglo y de la progresiva centralidad de Internet y de los medios conectivos: apología de la cotidianeidad, celebración de la inmediatez, de la proximidad, de la familiaridad; exaltación del hombre común, desacralización creciente de los asuntos políticos, reivindicación del diálogo, la escucha y la horizontalidad. ¿Qué capacidad de persuasión tiene una retórica romántica dentro de esta nueva ecología de medios y ante la configuración de nuevos estilos políticos de ciudadanía? ${ }^{32}$.

El creciente auge de gobiernos denominados "populistas" en América Latina, en Estados Unidos y en Europa parece desmentir la voz de quienes auguran el fin del pathos político y la imposición de una democracia de razones y consensos. De la misma manera, las diferentes orientaciones ideológicas de estos "populismos" y sus efectos de gobiernos nos advierten de los posibles logros y de las posibles fallas de esta clase de experiencias. En cualquier caso, los estudios discursivos tienen por objetivo aportar a su comprensión. La descripción lingüística es una dimensión fundamental de cualquier análisis del discurso político, pero el desafío de nuestra disciplina es avanzar mucho más allá de sus límites. Limitarse a la palabra parece un exceso de timidez ante la complejidad sensorial de fenómenos como la política.

\section{Referencias}

ALTAMIRANO, C.; SARLO, B. Ensayos argentinos. De Sarmiento a la vanguardia. Buenos Aires: Ariel, 1997.

ANGENOT, M. El discurso social: los límites históricos de lo pensable y lo decible. Buenos Aires: Siglo Veintiuno, 2010.

ANGENOT, M. A noção de arsenal argumentativo. In: ANGENOT, M. O discurso social e as retóricas da incompreensão. São Carlos: EdUFSCar, 2015.

ARISTÓTELES. El arte de la retórica. Buenos Aires: Eudeba, 2004.

BARTHES, R. La preparación de la novela: notas de cursos y seminarios en el Collège de France: 1978-1979 y 1979-1980. Buenos Aires: Siglo Veintiuno, 2005.

BARTHES, R. Lo neutro.Buenos Aires: Siglo Veintiuno, 2004.

BEACCO, J. -C. Matriz discursiva. In: CHARAUDEAU, P.; MAINGUENEAU, D. (Dirs.). Diccionario de análisis del discurso. Buenos Aires: Amorrortu, 2005, p. 376-377.

\footnotetext{
32 Véase Dalton (2014).
} 
CHARAUDEAU, P. Reflexiones para el análisis del discurso populista. Discurso \& Sociedad, v. 3, n. 2, p. 253-279, 2009. Disponible en: <http://www.patrickcharaudeau.com/Reflexiones-para-el-analisis-del.html>. Consultado el: 12 nov. 2018.

CHERESKY, I. Un signo de interrogación sobre la evolución del régimen político. In: CHERESKY, I. (Comp.). La política después de los partidos. Buenos Aires: Prometeo, 2006.

CICERÓN, M. Sobre el orador. Madrid: Gredos, 2002.

CURIA, W. El último peronista: ¿quién fue realmente Néstor Kirchner? Buenos Aires: Sudamericana, 2010.

DAGATTI, M. Contribuciones para una cartografía discursiva del primer kirchnerismo. In: BALSA, J. (Comp.). Discurso, política y acumulación en el kirchnerismo. Buenos Aires: Universidad Nacional de Quilmes y Centro Cultural Floreal Gorini, 2013, p. 75-98.

DAGATTI, M. Refundar la patria. Los legados del primer kirchnerismo. In: ARNOUX, E.; ZACCARI, V. (Eds.). Discurso y política en Sudamérica. Buenos Aires: Biblos, 2014, p. 165-200.

DAgatTi, M. El Partido de la Patria. Los discursos presidenciales de Néstor Kirchner. Buenos Aires: Biblos, 2017.

DALTON, R. Citizen Politics: public opinion and political parties in advanced industrial democracies. Los Angeles: SAGE, CQ Press, 1996.

MONTERO, A. S. «iY al final un día volvimos!»: los usos de la memoria en el discurso kirchnerista: 2003-2007. Buenos Aires: Prometeo, 2012.

PARRET, H. Las pasiones: ensayo sobre la puesta en discurso de la subjetividad. Buenos Aires: Edicial, 1995.

SALAVASTRU, C. Rhétorique et politique. Le pouvoir du discours et le discours du pouvoir. París: L'Harmattan, 2004.

SARLO, B. La audacia y el cálculo. Néstor Kirchner, 2003-2010. Buenos Aires: Sudamericana, 2011.

SCAVINO, D. Rebeldes y confabulados. Narraciones de la política argentina. Buenos Aires: Eterna Cadencia, 2012.

SIGAL, S.; VERÓN, E. Perón o muerte: los fundamentos discursivos del fenómeno peronista. Buenos Aires: Eudeba, 2004.

TERÁN, O. Historia de las ideas en la Argentina. Diez lecciones iniciales, 1810-1980. Buenos Aires: Siglo Veintiuno, 2009. 
Recebido em: 9 de abril de 2019

Aceito em: 3 de junho de 2019 